\title{
Systemic and enteric salmonellosis in calves
}

\section{Salmonelose sistêmica e entérica em bezerros}

\author{
Fernanda Morcatti Coura ${ }^{1}$; José Azael Zambrano Uribe ${ }^{1}$; \\ Pedro Veloso Facury Lasmar²; Antônio Último de Carvalho ${ }^{3}$; \\ Elias Jorge Facury Filho ${ }^{3}$; Marcus Vinicius Prado Silva ${ }^{4}$; \\ Andrey Pereira Lage ${ }^{3}$; Marcos Bryan Heinemann ${ }^{5 *}$
}

\begin{abstract}
This report describes the clinical manifestation of different Salmonella serovars in dairy calves. $S$. typhimurium was identified in faecal samples of a calf with rectal prolapse and in faecal samples and mesenteric lymph nodes of a calf with necrosis at the tip of the tail. S. agona was identified in faecal samples of a calf with diarrhoea but no other clinical manifestation, and S. dublin was observed in faecal and organ samples from a calf with neurological symptoms. Assays to differentiate between the main enteric pathogens (Enteropathogenic E. coli, rotavirus and coronavirus) were performed and were negative. Due to the negative impact of salmonellosis and occurrence of different serovars and clinical manifestations in calves, the correct diagnosis is important to identify control and prophylactic measures in a dairy herd.
\end{abstract}

Key words: Salmonellosis, calves, diagnosis, serovars

\section{Resumo}

Este relato de caso descreve a manifestação clínica de diferentes sorovares de Salmonella em bezerros leiteiros. A S. typhimurium foi identificado em amostras fecais de um bezerro com prolapso rectal e em amostras fecais e linfonodos mesentéricos de um bezerro com necrose na ponta da cauda. Já a S. agona foi identificada em amostras de fezes de um bezerro com diarréia, mas sem nenhuma outra manifestação clínica, e a $S$. dublin foi observada em amostras de fezes e de órgãos a partir de um bezerro com sinais clínicos neurológicos. Diagnóstico diferencial para os principais patógenos entéricos $(E$. coli enteropatogênica, rotavirus e coronavirus) foram realizados e foram negativos. Devido ao impacto negativo da salmonelose e a ocorrência de diferentes sorotipos e manifestações clínicas em bezerros, o diagnóstico correto é importante para identificar formas de controle e medidas profiláticas no rebanho leiteiro.

Palavras-chave: Salmonelose, bezerro, diagnóstico, sorovares

\footnotetext{
${ }^{1}$ Discente de Doutorado em Ciência Animal, Escola de Veterinária, Universidade Federal de Minas Gerais, UFMG, BH, MG, Brasil.E-mail: fernandamorcatti@yahoo.com.br; josezambranoucla@hotmail.com

2 Médico Veterinário, Eli e Lilly do Brasil Animal Health, BH, MG, Brasil. E-mail: pedro_vfl@hotmail.com

${ }^{3}$ Profs., Escola de Escola de Veterinária, Universidade Federal de Minas Gerais, UFMG, BH, MG. E-mail: ultimo@vet.ufmg.br; eliasfacury@gamil.com; aplage11@gmail.com

${ }^{4}$ Médico Veterinário Autônomo, BH, MG, Brasil. E-mail: marcusvp.silva@outlook.com

5 Prof., Faculdade de Medicina Veterinária e Zootecnia, Universidade de São Paulo, FMVZ USP, SP, Brasil. E-mail: marcosbryan@ usp.br

* Author for correspondence
} 


\section{Introduction}

The most common pathogens associated with diarrhoea in calves are rotavirus, coronavirus, Salmonella and diarrhoeagenic E. coli (BLANCHARD, 2012). Salmonellosis is a common disease in bovine (MOHLER et al., 2009). The genus Salmonella is divided into two species (S. enterica and S. bongori) and more than 2500 serovars. The different clinical manifestations of salmonellosis include diarrhoea, abortion, pneumonia, septic arthritis, meningitis, gangrene of distal extremities, and others, which are caused by the virulence of the serovars, infectious dose and host immunity. Serovars can be hostadapted, such as bovine host adapted S. dublin, or not host-adapted, such as S. typhimurium. The pathophysiology of diarrhoea associated with Salmonella infection is complex and involves inflammation and necrosis (MOHLER et al., 2009; NIELSEN, 2013).

Many serovars can infect cattle; Typhimurium and Dublin serovars are the most common. $S$. typhimurium is frequently associated with enteric disease in calves less than 2 months of age, and $S$. dublin is associated with young and adult cattle and is more invasive than $S$. typhimurium (MOHLER et al., 2009). Therefore, it is necessary to identify which serovars are associated with disease in cattle to understand the risks for not only cattle but also humans because certain serovars are potentially zoonotic. Adequate knowledge of these serovars will also assist in planning the best control and prophylactic methods (MOHLER et al., 2009; NIELSEN, 2013).

This report describes the clinical manifestation of different Salmonella serovars in dairy calves. Four different cases of disease in calves suggestive to salmonellosis were examined by veterinarians. Our variables included the main enteric infectious disease in calves.

\section{Case Report}

Three Holstein calves numbers 1, 2 and 3, aged 7, 8 and 15 days, respectively, were examined at the Veterinary Hospital of the Federal University of Minas Gerais, Brazil (VH-UFMG). The calves were reared at a dairy farm with intensive management, located at the Metallurgical Region of Minas Gerais. This farm had a history of elevated mortality of newborn calves. At the same period, another VH-UFMG Holstein calf (number 4) aged 40 days, was admitted from a dairy farm located in southern Minas Gerais; this farm had a history of high mortality of calves between 30 and 90 days old during the previous three months.

Calves 1, 2 and 3 exhibited lethargy, hyperthermia, diarrhoea with fibrin fragments and dehydration. Animal 4 presented neuropathy with clinical features of cortical syndrome. Animals 1, 2 and 3 were treated with antibiotics (gentamicin) and fluid therapy, but only one recovered (animal 1). Animal 4 died a few hours after admission. The animals that died were necropsied immediately after death, and macroscopic lesions were evaluated.

The clinical examinations of the three calves with diarrhoea revealed poor body condition, apathy, profuse watery diarrhoea, with fibrin fragments and undigested blood, hyperthermia, dehydration characterised by severe enophthalmia, a capillary refill time longer than 4 seconds and skin turgor longer than 6 seconds. In calf 1 (15 days old), tenesmus and rectal prolapse (Figure 1) were observed. In calf 2 ( 8 days old), the distal end of the tail had a blackish colour, loss of sensitivity, and a cold temperature, indicating necrosis. In calf 3 , only profuse watery diarrhoea was observed. Faeces of diarrheic calves were collected for bacteriological examination (E coli and Salmonella spp).

Calves with diarrhoea received parenteral treatment with gentamicin (4 $\mathrm{mg} / \mathrm{kg} \mathrm{BW}$ ) and oral and intravenous fluid therapy for three days. Because 
the intensity of clinical signs did not diminish, all calves were treated with flunixin meglumine at a dose of $2.2 \mathrm{mg} / \mathrm{kg}$ BW. Calf 1 recovered, but calves 2 and 3 died on the fifth day and were then necropsied. At necropsy, abundant translucent yellow liquid was observed within the abdominal cavity, and the small intestine was distended, primarily at the ileum, with liquefied content. This content was turbid and fetid with catarrhal aspect and contained mucus and fibrin fragments adhered to the intestinal mucosa, suggestive of fibrinous necrotizing enteritis. The mesenteric lymph nodes were oedematous and haemorrhagic and were collected for bacteriological examination.

Figure 1. A 15-day-old Holstein calf (calf 1) positive for Salmonella Typhimurium in faeces, with tenesmus and rectal prolapse.

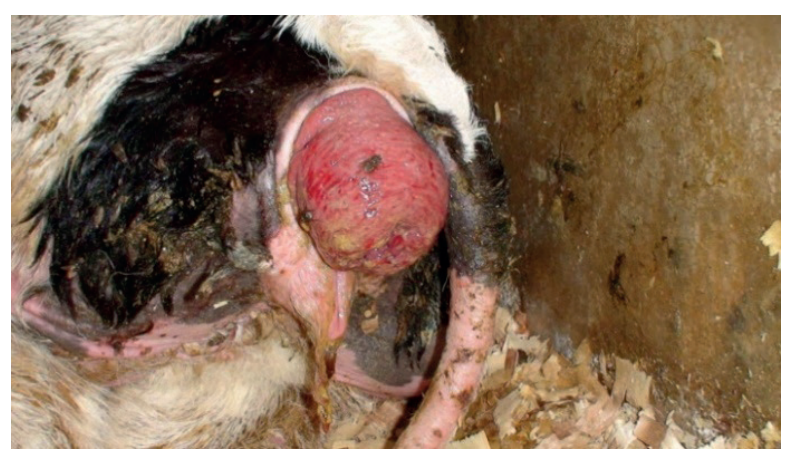

Calf 4 (40 days old) exhibited neuropathy, as characterised by lateral recumbency, severe depression, opisthotonos, paddling, a rectal temperature of $37.5^{\circ} \mathrm{C}$, bradypnea, and bradycardia. No external alterations were observed during the examination of the umbilical cord, but abdominal palpation of the internal navel, revealed swelling of the umbilical arteries, with increased sensitivity. This animal received no treatment and died shortly after the end of the clinical examination. The animal was then necropsied.

At necropsy, the umbilical arteries were adhered to the wall of ventral abdomen at the umbilical ring region, swollen and contained a purulent caseous material. Additionally, fibrin was observed at sectioned humeral radial ulnar joint and the lungs were congested. The meninges were thickened and white-greyish in colour with congestion of blood vessels and oedematous (Figure 2). Lesions indicating umbilical artery infection, arthritis and meningoencephalitis were observed, suggesting septicaemia, with the navel as a possible a gateway to the microorganism, with subsequent spread into the bloodstream.

Fragments of the brain, liver and lung were collected aseptically for bacteriological examination. Faecal samples were also collected. A microbiological examination was performed with faeces collected from calves. One gram of faeces was diluted in $3.0 \mathrm{~mL}$ of PBS (pH 7.2). From that suspension, $1.0 \mathrm{~mL}$ was inoculated into $9.0 \mathrm{~mL}$ of buffered peptone water (Difco Laboratories, Becton Dickinson and Company, Sparks, MD, USA) and incubated for $18-24 \mathrm{~h}$ at $37^{\circ} \mathrm{C}$. After incubation, one loopful of the pre-enrichment cultures was plated onto MacConkey agar plate (Difco Laboratories, Becton Dickinson and Company, Sparks, MD, USA), and $1.0 \mathrm{~mL}$ of culture was inoculated into 9.0 mL of tetrathionate broth (Difco Laboratories, Becton Dickinson and Company, Sparks, MD, USA) with $2 \mathrm{~mL}$ of iodine-iodide solution. Both media were incubated at $37{ }^{\circ} \mathrm{C}$ for $18-24 \mathrm{~h}$. The tetrathionate broth was then used to inoculate Hektoen and XLT4 (Difco Laboratories, Becton Dickinson and Company, Sparks, MD, USA) agar plates, followed by incubation for $20 \mathrm{~h}$ at 37 ${ }^{\circ} \mathrm{C}$. Three colonies from each agar plate, which exhibited characteristics of E. coli or Salmonella spp., were identified biochemically (QUINN et al., 1994). The isolates identified as Salmonella spp. from the Hektoen and XLT4 agar plates were further characterised by PCR (AMAVISIT et al., 2001) and serotyped at the Salmonella Reference Laboratory at the Instituto Oswaldo Cruz/Fundação Oswaldo Cruz (Rio de Janeiro, RJ, Brazil). E. coli was recovered from MacConkey plates, and multiplex PCR for $E$. coli virulence factor genes (FRANCK et al., 1998) 
was performed. A bacteriological examination was also performed on samples of the mesenteric lymph nodes of calves 2 and 3 , and from fragments of the brain, liver and lung from calf 4 using sterile scissors to cut the organs into small pieces. All samples were cultured as described above for both E. coli and Salmonella. A silver-stained PAGE procedure and a RT PCR were used to detect rotavirus and bovine coronavirus (BARRY et al., 2009) respectively. The bacteriological examination for Enteropathogenic E. coli was negative in the faecal samples and organs of all calves. Additionally, rotavirus and coronavirus were not detected in the faeces of the calves.

Figure 2. Brain of a 40-day-old Holstein heifer (calf 4) exhibiting opacity of the meninges (white-greyish colour), oedema and congestion. Salmonella Dublin was isolated from brain tissue.

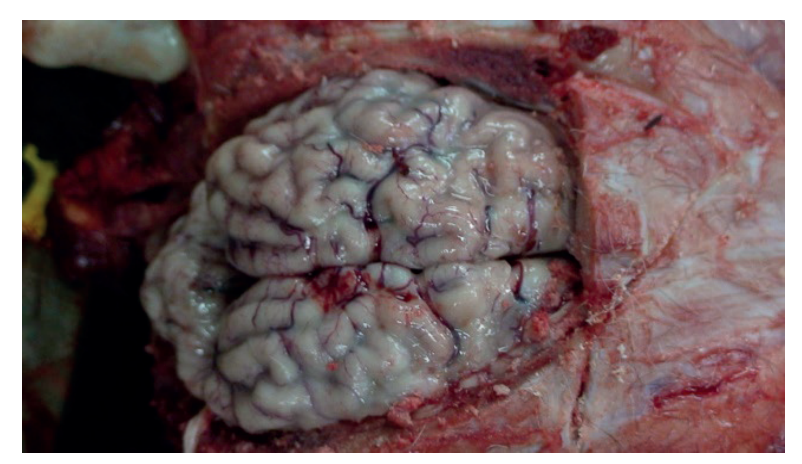

Salmonella spp. was isolated and identified by biochemical and PCR assays from the faecal and organ samples. S. typhimurium was detected in faecal sample of calf with rectal prolapse (calf 1 ) and in faecal samples and the mesenteric lymph nodes of the calf with necrosis at the tip of the tail (calf2). At the same herd, one calf with diarrhoea but no other clinical manifestations (calf 3 ) had faeces positive for S. agona. S. dublin was detected in brain and lung of calf with neurological symptoms (calf 4). Therefore, based on clinical signs, bacteriological findings and gross findings, a final diagnosis of salmonellosis was established.
Bacteriological culture with pre-enrichment, selective media, plating and bacteria detection are important methods for identifying Salmonella (NIELSEN, 2013). Together with pathogen detection, clinical history and necropsy are important tools in the diagnosis, prevention and treatment of calf disease pathogenesis (BLANCHARD, 2012). All of these diagnostic tools were performed during this study.

The macroscopic changes found at necropsy of the animals with diarrhoea ( 2 and 3 ) are in agreement with those reported in a recent experimental study with $S$. typhimurium and $S$. newport in calves, during which diarrhoea was present with the formation of pseudomembranes, focal to diffuse haemorrhage and necrosis at the mucosa of the ileum and in some cases reaching the cecum and colon mucosal. The authors also report swelling and congestion of mesenteric nodes (HATHAWAY et al., 1993; SNIDER et al., 2014). Oral infection caused by $S$. typhimurium in calves is restricted to the intestine and mesenteric lymph nodes, which causes increased vascular permeability and severe inflammatory infiltration of neutrophils (NIELSEN, 2013). A loss of integrity of the intestinal epithelium leads to diarrhoea due to exudative inflammation, with subsequent formation of a pseudomembrane in the final part of the ileum and the initial part of the colon (MOHLER et al., 2009; NIELSEN, 2013).

The severity of clinical disease is associated with various factors, including strain virulence, challenge dose, calf age and efficiency of passive immunity (MOHLER et al., 2009). Calves are infected by different serovars of Salmonella. S. typhimurium is most frequently associated with enteric disease, and $S$. dublin presents with invasive clinical manifestations, such as meningoencephalitis, septic arthritis, respiratory disease and occasionally, gangrenous necrosis of the distal extremities (MOHLER et al., 2009). In our case report, the host-adapted $S$. typhimurium and dublin were more pathogenic in calves, whereas the non-adapted $S$. 
agona caused enteritis and no systemic illness, thus reinforcing the importance of diagnosis.

The absence of changes in the intestine and mesenteric lymph nodes in calf 4 , which presented neuropathy, suggests that the $S$. dublin infection was not oral. The alterations found in the umbilical arteries indicated that this area might have been the gateway ofinfection, followed by bacteraemia and the development of arthritis and meningoencephalitis. A study evaluating the histopathological and microbiological characteristics of slaughtered calves with inflammation of the navel and its associated structures showed that $S$. typhimurium can invade these tissues and spread to the liver (HATHAWAY et al., 1993; PATTERSON-KANE et al., 2001).

Umbilical infection and septicaemia by Salmonella have been reported in different species. Omphalitis was reported in a neonatal foal with isolation of S. agona in the navel, lung, brain, kidney and liver but without macroscopic and microscopic changes in the intestine (PATTERSON-KANE et al., 2001). Omphalitis and septicaemia caused by $S$. newport were reported in a neonate whale (Orcinus orca) from California (COLEGROVE et al., 2010). In humans, $S$. weltervreden has been isolated and identified in umbilical tissues of a neonate born by caesarean section with clinical signs of sepsis (PATIL et al., 2006). These reports reinforce the possibility that the navel might have been the gateway of infection and septicaemia observed with S. dublin in heifer 4.

The above cases demonstrate that the various clinical manifestations of salmonellosis and these different presentations can be related to the serovar involved. These differences reinforce the necessity to adopt techniques to isolate and identify these agents because Salmonella can continue to circulate in the herd as sub-clinical infections, and animals can become carriers (MOHLER et al., 2009).

Animals that shed Salmonella intermittently or for months are considered persistently infected carries, namely active carries (continually excreting the bacteria), passive carries (excreting bacteria without clinical signs) and latent carriers (the infected animal that may or may not excrete), and the identification of these carries is needed to control Salmonella (NIELSEN, 2013). The persistence of Salmonella for 2 years in a calf facility has been reported (BLANCHARD, 2012).

\section{Conclusion}

When addressing disease in calves, diagnosis is important, especially for salmonellosis infections due to its impact in the herd, virulence and diversity of serovars and clinical manifestations. It is important to identify whether Salmonella is involved in calf disease to determine risk factors and to implement prophylactic, control, and treatment measures. Diagnosis of Salmonella infection is also important to evaluate the impact of vaccine implementation.

\section{Acknowledgments}

This work was supported by the Conselho Nacional de Desenvolvimento Técnico e Científico - CNPq, Pró-Reitoria de Pesquisa da UFMG-PRPq and Fundação de Amparo à Pesquisa do Estado de Minas Gerais - FAPEMIG.

\section{Competing interests}

The authors declare that they have no competing interests.

\section{References}

AMAVISIT, P.; BROWNING, G. F.; LIGHTFOOT, D.; CHURCH, S.; ANDERSON, G. A.; WHITHEAR, K. G.; MARKHAM, P. F. Rapid PCR detection of Salmonella in horse faecal samples. Veterinary Microbiology, Barcelona, v. 79, n. 1, p. 63-74, 2001.

BARRY, A. F.; ALFIERI, A. F.; STIPP, D. T.; ALFIERI, A. A. Bovine coronavirus detection in a collection of diarrheic stool samples positive for group a bovine rotavirus. Brazilian Archives of Biology Technology, Curitiba, v. 52, p. 45-49, 2009. Special Number. 
BLANCHARD, P. C. Diagnostics of dairy and beef cattle diarrhea. Veterinary Clinics of North America Food Animal Practice, Maryland Heights, v. 28, n. 3, p. 443464, 2012.

COLEGROVE, K. M.; ST LEGER, J. A.; RAVERTY, S.; JANG, S.; BERMAN-KOWALEWSKI, M.; GAYDOS, J. K. Salmonella Newport omphaloarteritis in a stranded killer whale (Orcinus orca) neonate. Journal Wild Diseases, Lawrence, v. 46, n. 4, p. 1300-1304, 2010.

FRANCK, S. M.; BOSWORTH, B. T.; MOON, H. W. Multiplex PCR for enterotoxigenic, attaching and effacing, and Shiga toxin-producing Escherichia coli strains from calves. Journal of Clinical Microbiology, Barcelona, v. 36, n. 6, p. 1795-1797, 1998.

HATHAWAY, S. C.; BULLIANS, J. A.; JOHNSTONE, A. C.; BISS, M. E.; THOMPSON, A. A pathological and microbiological evaluation of omphalophlebitis in very young calves slaughtered in New Zealand. New Zealand Veterinary Journal, Wellington, v. 41, n. 4, p. 166-170, 1993.

MOHLER, V. L.; IZZO, M. M.; HOUSE, J. K. Salmonella in calves. Veterinary Clinics of North America Food Animal Practice, Maryland Heights, v. 25, n. 1, p. 37-54, 2009.
NIELSEN, L. R. Review of pathogenesis and diagnostic methods of immediate relevance for epidemiology and control of Salmonella Dublin in cattle. Veterinary Microbiology, Barcelona, v. 162, n. 1, p. 1-9, 2013.

PATIL, A. B.; KRISHNA, B. V.; CHANDRASEKHAR, M. R. Neonatal sepsis caused by Salmonella enterica serovar Weltevreden. Southeast Asian Journal of Tropical Medicine and Public Health, Bangkok, v. 37, n. 6, p. 1175-1178, 2006.

PATTERSON-KANE, J. C.; BAIN, F. T.; DONAHUE, J. M.; HARRISON, L. R. Meningoencephalomyelitis in a foal due to Salmonella Agona infection. New Zealand Veterinary Journal, Wellington, v. 49, n. 4, p. 159-161, 2001.

QUINN, P. J.; CARTER, M. E.; MARKEY, B.; CARTER, G. R. Enterobacteriaceae. In: QUINN, P. J.; CARTER, M. E.; MARKEY, B.; CARTER, G. R. (Ed.). Clinical veterinary microbiology. $9^{\text {th }}$ ed. London: Mosby, 1994. p. 209-236.

SNIDER, T. A.; GULL, T.; JACKSON, T. A.; MARTINEZ-BECERRA, F. J.; PICKING, D. R.; PICKING, W. D.; PICKING, W. L. Experimental salmonellosis challenge model in older calves. Veterinary Microbiology, Barcelona, v. 170, n. 1-2, p. 65-72, 2014. 